\title{
Aydın İline Olan İç Göçün Kadınların Genel Sağlık ve Üreme Sağlığı Durumlarına Etkisi $\infty$
}

\author{
Hilmiye AKSU ${ }^{1}$, Hande YAĞCAN ${ }^{2}$, Safiye ÖZVURMAZ ${ }^{3}$, Mevlüt TÜRE ${ }^{4}$
}

\section{öz}

Amaç: Bu çalışmada Aydın İli'ne göç eden üreme çağındaki kadınların genel sağlık ile üreme sağlığı durumlarını ve etkileyen faktörleri belirlemek amaçlanmıştır.

Gereç ve Yöntem: Çalışma, analitik ve tanımlayıcı tipte olup verileri Aydın İli'nin Aile Sağlığı Merkezlerine başvuran 331 kadından "Göç Eden Kadınların Genel Sağlık ve Üreme Sağlığı Durumlarına İlişkin Anket Formu" ve "Genel Sağlık Anketi" kullanılarak toplanmıştır.

Bulgular: Göçmen kadınların \%71.3'ü göç etmekten çok memnun olduklarını ifade etmelerine rağmen, göç \%14.5'inin ekonomik durumunu olumsuz etkilemiştir. Kadınların \%26.9'unun genel sağlık durumu riskli bulunmuştur. Riskli kadınların, gebelik, abortus, küretaj ve ölü doğum sayı ortalamaları sağlıklı gruptan fazla olup, canlı doğum, yaşayan çocuk sayısı ve ilk gebe kalma yaş ortalamaları daha düşüktür. Riskli kadınların yaş ortalamaları sağlıklı gruba göre daha genç ( $U: 8849.0, p<0.01)$ ve göç edilen yerde yaşama süreleri ise daha uzun bulunmuştur ( $U: 9093.5, p<0.02)$. Kadınların isteyerek evlenme durumlarının genel sağlık durumlarını etkilediği saptanmıştır $\left(X^{2}=10.032 ; p<0.00\right)$.

Sonuç: Genel sağlık durumu riskli çıkan kadınların obstetrik bulgularının daha kötü durumda olduğu ve bu bulguların göç edilen yerde yaşanılan sürenin artması ile doğru orantılı olarak kötüleştiği görülmüştür. Yaşanılan sağılı sorunları arasında menstrual siklus düzensizliği ve ruhsal bunalım gibi problemler yer almaktadır. Göçmen kadınlara; aile planlaması yöntemleri, gebelik ve genel sağılı taramaları konuları ile ilgili eğitimler verilmesi ve psikolojik destek sağlanması gerekmektedir.

Anahtar kelimeler: Göç, kadın sağlığı, üreme sağ|ığı

\begin{abstract}
The Effect of Internal Migration on the General and Reproductive Health Status of Women Migrating to Aydın Province

Aim: This study aims to determine the general and reproductive health status of women of reproductive age who migrated to Aydın Province and the factors affecting them.

Material and Methods: The data of this analytical and descriptive study were collected using "General Health Questionnaire" and "Immigrant Women's General and Reproductive Health Status Questionnaire" from 331 women who applied to Family Health Centers of Aydın Province.

Results: Although $71.3 \%$ of the immigrant women stated that they were very satisfied with immigration, the migration negatively affected the economic situation of $14.5 \%$ of them. The general health status of $26.9 \%$ of the women was found to be risky. The average number of pregnancies, abortions, curettage, and stillbirths of the risky women is higher than the healthy group, and the average age of the first pregnancy, the number of living children, and live births are lower. The mean age of the women at risk was found to be younger ( $U: 8849.0, p<0.01)$ and the duration of living in the migrated place was longer than the healthy group (U: 9093.5, $p<0.02$ ). The general health status of women was affected by their marriage consent status $\left(X^{2}=10.032 ; p<0.00\right)$.

Conclusion: The obstetric findings of risky women were in worse condition, and these findings worsened in direct proportion with the increase in the time spent in the migrated place. Health problems experienced by women include menstrual cycle disorder and mental distress. Immigrant women should be educated about family planning methods, pregnancy, general health scans, and provided psychological support.
\end{abstract}

Keywords: Immigration, reproductive health, women's health

1Prof. Dr., Aydın Adnan Menderes Üniversitesi Hemşirelik Fakültesi, Doğum-Kadın Sağlığı ve Hastalıkları Hemşireliği Anabilim Dalı, Aydın, Türkiye, E-posta: hilmiyeaksu@yahoo.com, Tel: 05424107035, ORCID: 0000-0001-6975-3172

${ }^{2}$ Dr. Öğretim Üyesi, Dokuz Eylül Üniversitesi Hemşirelik Fakültesi, Doğum ve Kadın Hastalıkları Hemşireliği Anabilim Dalı, İzmir, Türkiye, E-posta: hande.yagcan@gmail.com, Tel: 05556444051, ORCID: 0000-0001-9658-0449

${ }^{3}$ Doç. Dr., Aydın Adnan Menderes Üniversitesi Hemşirelik Fakültesi, Halk Sağlığı Hemşireliği Anabilim Dalı, Aydın, Türkiye, E-posta: sozvurmaz@hotmail.com, Tel:05374746531, ORCID: 0000-0002-1842-3058

4Prof. Dr., Aydın Adnan Menderes Üniversitesi Tıp Fakültesi, Temel Tıp Bilimleri Bölümü, Biyoistatik Anabilim Dalı, Aydın, Türkiye, E-posta: mevlut.ture@adu.edu.tr, Tel: 02562182000 - 2706, ORCID: 0000-0003-3187-2322

Geliş Tarihi: 27 Nisan 2020, Kabul Tarihi: 05 Mayıs 2021

Atıf/Citation: Aksu H, Yağcan H, Özvurmaz S, Türe M. Aydın İline Göç Eden Kadınların Genel Sağlık ve Üreme Sağlığı Durumları Üzerine iç̧ Göçün Etkisi. Hacettepe Üniversitesi Hemşirelik Fakültesi Dergisi 2021;8(2):213-222. DOI: 10.31125/hunhemsire.968908 


\section{GíRiş}

Göç; belirli bir sosyal yapı içindeki birey ve grupların ekonomik, sosyal, psikolojik, siyasal, kültürel, doğal olaylar ve terör gibi nedenlerle, hayatlarının gelecekteki kısmının tamamını veya bir kısmını geçirmek üzere, tamamen ya da geçici bir süre için bir yerden (kent, kasaba, köy) bir yere yerleşmek amacıyla yaptıkları coğrafi yer değiştirmedir. Göç, genel olarak, iç göç (ülke içi) ve dış göç (ülkeler arası) şeklinde meydana gelir. Göçler; isteğe bağlı, zoraki, devamlı ya da geçici, aşamalı/aşamasız, mevsimlik, günü birlik iş gücü, yaz/tatil, transit, net ve illegal göç şeklinde olabilmektedir ${ }^{1,2}$.

Göç, insanlık tarihinin bütün dönemleri boyunca var olan bir olgudur. Sonuçları itibariyle sosyal, ekonomik, kültürel ve psikolojik birçok öğeyi içinde barındırır. Göç her zaman önemli bir toplumsal değişim nedenidir ${ }^{3}$. Birleşmiş Milletler (UN) 2018 verilerine göre; dünyada 2000 ile 2017 yılları arasında göçmen oranı \%50 artmış ve 258 milyona ulaşmıştır. Bu göçmenlerin 78 milyonu Avrupa ve 80 milyonu Asya'da bulunmaktadır ${ }^{4}$. Türkiye İstatistik Kurumu (TÜiK) 2019 yılı adrese dayali nüfus kayit sistemi sonuçları doğrultusunda oluşan göç istatistikleri verilerine göre, Aydın ilinin net göç hızının 3.84 olduğu, en çok göçü 20-24 yaş aralığında bulunan bireylerden ve sırasıyla İzmir, İstanbul ve Ankara illerinden aldığı ve Türkiye genelinde en yüksek net göç hızına sahip 14. il olduğu belirtilmiştir ${ }^{5}$.

Göç hareketleri özellikle kadınları etkilemektedir. Türkiye'de göç sürecinin kadınlar için beraberinde getirdiği etkiler arasında cinsel yolla bulaşan hastalıklar, ana-çocuk sağlığı ve aile planlaması hizmetlerinden yeterince yararlanılamamasına bağlı; çok ve sık aralıklarla çocuk sahibi olma, doğum öncesi bakım hizmetlerinin alımının az olması, perinatal ve postnatal bebek ölüm hızlarının, evde sağlık personeli olmaksızın yapılan doğum oranının yüksek olması saptanmıştır. Bu etkilere ilave olarak; kadınların kültürel nedenlerle yabancı bir ortamdaki hareket özgürlüklerinin giderek kısıtlanması, erkeklere oranla iş gücü piyasalarına katılımda zorlanması ve bu yüzden göç etmiş olan kadınların 'ev kadını' rolünü eskisine oranla daha fazla benimsemek zorunda kalması ve ev temizlik işçiliği gibi daha prestiji ve geliri düşük işlerde çalıştırılması yer almaktadır ${ }^{2,6,7}$.

Göçmen ailelerde geldikleri yeni ortama uyum sağlama aşamasında, erkeklerin yeni kişilerle tanışması ve ailesinden uzaklaşması, evlilikte eşler arasında problemler yaşanmasına neden olmakta ve boşanma oranları artmaktadır ${ }^{2,8}$. Ayrıca özellikle zoraki göçün ruh sağlığını olumsuz yönde etkilediği ve kadın göçmenlerin erkek göçmenlere göre daha fazla duygusal zorlanma yaşadığı belirtilmektedir ${ }^{9}$.

Pek çok dünya ülkesinde kadının statüsü düşüktür ve kadın göçmen olmak, durumu iki kat daha olumsuz yapabilmektedir. Göçmen kadınlar hem kadın oldukları hem de göçmen oldukları için cinsel taciz, tecavüz ve şiddette maruz kalabilmektedirler ${ }^{3}$. Göçmen kadınların karşılaştıkları bir diğer sorun fuhuşa zorlanmalarıdır. Bu durum aynı zamanda kadınları cinsel yolla bulaşan hastalıklar ve HIV enfeksiyonu açısından risk grubuna sokmaktadır8,10.
Göçmen kadınların sağlık bakım hizmetlerinden yararlanmasını etkileyen etmenler arasında dil engeli, sağlık hizmetlerinin maliyeti, sağıı hizmetlerine nasıl ulaşacaklarını bilmeme, ayrımcılığa uğrama korkusu ve sosyal güvencenin olmaması yer almaktadır. Göçmen kadınların sigortasız olduğu ve sigortası olmayan kadınların koruyucu sağlık hizmeti, ruh sağlığı, diş ve acil bakım hizmetlerini en az oranda kullandıkları belirtilmektedir. Devlet sigortası olanların da özel sigortası olanlara göre yine sağlık bakımından daha az yararlandıkları bildirilmektedir8,11-15.

Göçmen kadınlarla ilgili Avrupa ülkelerinde yapılan pek çok epidemiyolojik çalışmada gebelik sonuçları çelişkili olarak verilmektedir. Gelişmiş ülkelerde, göçmen annelerin gebelik sonuçlarının yerli annelere göre daha kötü olduğu belirtilmektedir. Yapılan çalışmalarda göçmen kadınların yerli kadınlara oranla daha çok düşük doğum ağırlıklı bebek (DDAB) doğurduğu, preeklampsi, preterm doğum, uterin rüptür, perinatal mortalite ve konjenital anomali risklerine sahip olduğu saptanmıştır ${ }^{16,17}$.

Sonuç olarak; Göçün beraberinde getirdiği risk faktörleri nedeniyle özellikle kadınlar ve çocuklar sağlık açısından diğer gruplara göre daha fazla risk altındadırlar. Göç sonrasında Abraham Maslow'un insanların temel gereksinimleri olan; fizyolojik (barınma), güvenlik, sosyal (çocuklar, eş), kendini gerçekleştirme ve estetik (kendine güven) gereksinimlerin karşılanmasına ilişkin sorunlar yaşanabilir. Bunun için de özellikle birinci basamak sağlık kuruluşlarında çalışan hemşirelerin; göçmen kadınların sağlık durumlarında etkili olan biyolojik, sosyal, kültürel değişkenleri, sağlık davranışlarını, inançlarını ve yaşam biçimlerini değerlendirmesi gerekmektedir. Belirledikleri yetersiz olunan alanlarla ilgili kültürel farklılıkları dikkate alarak eğitimler düzenleyip ve üreme sağlığı destek programları hazırlayarak göçmen kadınların bilgi, tutum ve davranışlarını geliştirmelidir.

Ayrıca göç eden bireylerin karşılaştıkları ön yargılar giderilip, diğer bireylerle iletişim kurmaları sağlanarak, destekleyici bir çevre yaratılmalı, sanitasyona önem verilmeli, sağıı hizmetleri yapılan ev ziyaretleriyle daha kolay ulaşılır ve pratik çözüm önerileriyle daha az maliyetli hale getirilmelidir2,6,18. Sağlık çalışanları içerisinde hemşireler ve ebeler tüm bu sorunların çözümünde eşsiz bir yere sahiptir. Koruyucu sağlık hizmetleri kapsamında; göçmen kadınların üreme sağlığı sorunlarını çözmede, kontreseptif yöntemlere ulaşmalarını ve kullanmalarını sağlamada, anne bebek ölümlerini azaltmada çok önemli rollerinin olduğunu fark etmeli ve kadınlara yardım etmelidirler ${ }^{7}$. Çünkü kadının, ailenin sağlığının sürdürülmesinde ve geliştirilmesindeki rolü çok önemlidir. Bu çalışmanın hemşire ve ebelerin tüm bu rolleri ve görevlerini yerine getirmelerine, göçmen kadınların yaşadıkları sorunların farkında olmalarını, sağlık hizmetlerini onlar için daha ulaşılabilir hale getirmelerini, göçmenlere karşı olumlu bakış açısı geliştirmelerini, bu sorunlara yönelik uygun çözüm yolları üretmeleri ve bakım kalitesini artırmaları doğrultusunda katkı sağlaması beklenmektir. 


\section{Araştırmanın Amacı}

Bu çalışma Aydın Ili'ne göç eden üreme çağındaki kadınların genel sağlık ve üreme sağlığı durumlarını belirlemek ve etkileyen faktörleri incelemek amacı ile yapılmıştır. Bu çalışmanın ikincil amacı iç göçün kadın sağlığına etkilerini ortaya çıkartmak ve ileride oluşturulacak sağlığı geliştirme programlarına temel oluşturmasıdır.

\section{GEREÇ ve YÖNTEM}

\section{Araştırmanın Türü}

Analitik ve tanımlayıcı tipte bir çalışmadır.

\section{Araştırma Evren ve Örneklemi}

Araştırmanın evreni, Aydın Ili'nin en çok iç göç alan Kadıköy (683 kadın), Ovaeymir (820 kadın) ve Tepecik (780 kadın) bölgelerine bağlı belirlenen üç ayrı Aile Sağlığı Merkezine (ASM) kayıtlı olan, Doğu ve Güneydoğu Anadolu bölgesinden herhangi bir tarihte göç etmiş, 15-49 yaş arasında ve üreme çağında olan toplam 2283 kadından oluşmaktadır.

Araştırmanın örneklem büyüklüğü $\alpha=0.05$, iki yönlü hipotez kullanılarak \%80 güç için kötü sağlık durumu algısı odds oranı 1.65 alınarak örneklem büyüklüğü en az 288 olarak belirlenmiştir ${ }^{19}$. Örneklemde yaklaşık olarak \%15 kayıp olasılığı hesaplandığında 329 örneklem ile çalışılması planlanmış, araştırmaya katılmaya gönüllü ve tabakalı rastgele örnekleme yöntemine göre seçilmiş olan 331 kadına ulaşılmıştır. Araştırmaya dahil edilen 311 göçmen kadın, ilgili ASM'deki araştırma kriterlerine uyan göçmen kadın sayısının tabakalı rastgele örnekleme yöntemine göre hesaplanması ile belirlenmiştir (Tablo 1).

Tablo 1. Tabakalı Rastgele Örnekleme Yöntemine Göre Aydın ili Göç Alan Bölgelerinden Çalışmaya Alınan Kadın Sayısı

\begin{tabular}{|c|c|c|c|}
\hline Bölge & $\begin{array}{c}\text { Kadın } \\
\text { sayısı }\end{array}$ & Tabaka ağırlığı & $\begin{array}{c}\text { Örnekleme alınacak } \\
\text { kadın sayısı }\end{array}$ \\
\hline Kadıköy & 683 & $583 / 2283=0.30$ & $0.30 \times 329=99$ \\
\hline Ovaeymir & 820 & $820 / 2283=0.36$ & $0.36 \times 329=118$ \\
\hline Tepecik & 780 & $780 / 2283=0.34$ & $0.34 \times 329=112(114)^{*}$ \\
\hline Toplam & 2283 & & 329 \\
\hline
\end{tabular}

* Tepecik grubunda planlanandan daha fazla kadına ulaşılld.

Araştırmanın Yapıldığı Yer ve Özellikleri

Araştırmanın verileri Aydın İli'ne Türkiye'nin Güneydoğu ve Doğu bölgelerinden iç göçle gelmiş olan kadınların yoğun olduğu ve en çok göç alan Kadıköy, Ovaeymir ve Tepecik bölgelerine bağlı Efeler 8 Nolu ASM, Çeştepe ASM ve Ovaeymir ASM'lerinden Nisan 2016- Ocak 2017 tarihleri arasında toplanmıştır.

\section{Veri Toplama Araçları}

Verileri toplamak için, Göç Eden Kadınların Genel Sağlık ve Üreme Sağlığı Durumlarına illişkin Anket Formu ve Genel Sağlık Anketi (GSA) kullanılmıştır.

Genel Sağlık ve Üreme Sağlığı Durumlarına ílişkin Anket Formu

Araştırmacılar tarafından literatürden yararlanılarak oluşturulan, 28 adet sosyo-demografik özellikleri (yaş, evlilik, eğitim vb.) ve 16 adet üreme sağlığı ile ilgili verileri sorgulayan toplam 44 sorudan oluşan anket formu kullanılmıştır ${ }^{2,3,6-18}$

\section{Genel Sağlık Anketi}

Genel Sağlık Anketi'nin 12 ve 28 sorulu formları vardır. Bu çalışmada 12 soruluk formu (GSA12) kullanılmıştır. Dörtlü likert tipi bir ölçektir. General Health Questionnaire anketin özgün adıdır. GSA12, 1988'de Goldberg ve Williams tarafından geliştirilmiştir ${ }^{20}$. Kılıç tarafından 1996 yılında Türkçeye uyarlanmıştır ${ }^{21}$. Türkçe formunun güvenirlik çalışmasında Cronbach alfa katsayısı GSA12 için 0.78 bulunmuştur. Çalışmamızda ise Cronbach alfa katsayısı GSA12 için 0.85 bulunmuştur Türkçe formunun geçerlilik çalışmasında ROC analizi uygulanarak ölçüt geçerliliği elde edilmiştir. Bu amaçla GSA tipi puanlama ile GSA12 için kesme puanı 1 veya 2 olarak hesaplanmıştır.

Sağlıklı bireylere birinci basamak sağlık hizmetine başvuranlar ve bedensel hastalığı olan psikiyatri dışı hasta gruplarına uygulanabilir. Burada her bir maddenin ilk 2 yanıtı 0 ve son 2 yanıtı ise 1 puan alır ve toplam puan bunların toplanması ile elde edilir. Bu çalışmada kesme noktası 2 alınmıştır, 3 ve üzeri puan alan risk grubunda kabul edilmiştir.

\section{Veri Toplama Araçlarının Uygulanması}

Aile sağlığı merkezine herhangi bir neden ile başvuran kadınlara araştırma hakkında bilgi verildikten sonra gönüllü olanlar ve araştırmaya dahil olma kriterlerine uyanlar ile çalışılımıştır.

Veriler ev ziyaretlerinde bulunularak araştırmacılar tarafından yüz yüze görüşme tekniği kullanılarak toplanılmıştır. Yazılı onam vermeyen, o bölgede doğmuş, büyümüş 15-49 yaş gurubu, Türkçe konuşamayan ve tanı almış psikiyatrik hastalığı olan kadınlar araştırmaya alınmamıştır.

\section{Verilerin Analizi}

Elde edilen verilerin ortalama ve standart sapmaları hesaplanmıştır. Bağımsız değişkenlerin karşılaştırılmasında; veriler göçmen kadınların GSA'ya doğrultusunda belirlenen sağlık risk gruplarının Kolmogorov-Smirnov analizine göre normal dağılım göstermediği için Mann-Whitney $U$ ve Kruskall Wallis testleri kullanılmıştır $(p<0.00)$. Verilerin analzinde ayrıca ki-kare, kolerasyon ve Chaid Analizi kullanılmıştır. Veriler .05 anlamlılık düzeyinde, SPSS 22.0 programı kullanılarak analiz edilmiştir.

\section{Araştırmanın Etik Boyutu}

Araştırmanın uygulanabilmesi için, Aydın Adnan Menderes Üniversitesi Tıp Fakültesi Klinik Araştırmalar Etik Kurulundan 2016/813 karar numaralı etik kurul izni ve Aydın Halk Sağlığı Müdürlüğ̈̈'nden izin alınmıştır. Görüşme öncesinde, kadınlara araştırmanın amacı, araştırmadan sağlanacak yararlılıklar, görüşme için harcayacağı zaman konusunda açıklamalar yapılmış ve yazılı onamları alınmıştır.

\section{Araştırmanın Sınırlılıkları}

Bu çalışmanın sınırılıkları; çalışmanın küçük bir göçmen kadın grubuna yapılmış olmasıdır. Bu nedenle, çalışmadan elde edilen bulgular tüm göçmen kadınlara genellenemez, sadece çalışmanın yapıldığı ASM'lerin bulunduğu bölgelerde yaşamakta olan göçmen kadınlar için genelleme yapılabilir.

\section{BULGULAR}

Çalışmaya katılan göçmen kadınların yaş ortalaması 32.73 \pm 8.18 (min:17, max:50) olup, \%97'si evli, \%44.7'si eşi ile akraba ve \%89.1'i isteyerek evlenmiştir. Kadınların \%33.5'inin okuma yazması bulunmamakta, \%94.6'sı ev hanımı, \%18.4'ü göç nedeniyle çalıştığı işten ayrılmış, 
\%81.3'ünün sağıık güvencesi bulunmaktadır. Ayrıca \%36.3'ünün geliri giderinden az olup, \%38.4'ü geniş aile olarak yaşamaktadır. Göç ettikleri yerler incelendiğinde; \%29.9'u Ağrı, \%14.8'i Bitlis ve \%10.6'sı Muş'tan göç etmiştir. Göç etme nedenlerinde ise \%47.7 ile bireysel (eğitim, evlilik, tayin vb.), \%36.3 ekonomik, \%10.3 ailevi (eşin ve ya ebeveynin yanına gelmesi) nedenler yer almaktadır.

Aydın Ili'ne göç eden bu kadınların burada ortalama yaşama süresi $16.41 \pm 9.70$ yıl (min:1, max:50) olup, \%71.3'ü buraya göç etmekten çok memnun olduklarını ve \%63.4'ü tekrar şansı olsa yine Aydın'a göç edeceğini ifade etmiştir. Tekrar göç ederdim diyenlerin \%45'i Aydın'ın memleketlerinden daha güzel olduğunu, $\% 42.1^{\prime} i$ burada daha iyi imkanlara sahip olduğunu ve \%7.4'ü evlilik nedeniyle geldiğini belirtmiştir. Kadınların \%27.5'i tekrar şansı olsa yine buraya göç etmek istemediklerini belirtmiştir. Bu kadınların da, \%59.2'si eşinin ailesi ile sorun yaşadıklarını, \%27.6'sı memleket ve aile özlemi çektiklerini, \%7.9'u ekonomik sorunlar ve \%1.3'ü dil engeli yaşadığını, \%1.3'ü terör olmasa gelmeyeceğini, \%2.6'sı ruh sağlığının bozulduğunu ifade etmiştir. Genel olarak kadınların \%61.9'u memleketlerine geri dönmek istememektedir.

Göç etmek kadınların \%14.5'inin ekonomik durumunu, \%6.3'nün sağlığını ve \%6'sının yaşadığı ev şartlarını olumsuz etkilerken, \%65'i bir değişiklik yaşamadıklarını belirtmişlerdir. Ayrıca kadınların \%8.8'i göçten sonra sağlığının düzeldiğini, \%21.1'i bozulduğunu ve \%70.1'i ise herhangi bir değişiklik yaşamadığını ifade etmiştir. Kadınların \%69.4'ü sağlık sorunu yaşamazken, yaşanılan sağlık sorunları arasında \%12.7 menstrual siklus düzensizliği, \%9.1 ruhsal bunalım ve \%3.6 sinirlilik ve mutsuzluk yaşadıkları saptanmıştır. Kadınların \%69.1'i genel sağlık durumunu iyi, \%23'ü orta ve \%7.9'u kötü olarak algıladığını belirtmiştir.

Göçmen kadınların üreme sağlığı durumları incelendiğinde; $\% 78.9$ 'unun gebeliği planlı olup, \%60.2'si aile planlaması yöntemi kullanmakta olup bunların \%25.4'ü hap, \%21.8'i kondom ve \%20.7'si rahim içi araç kullanmaktadır. Kadınların \%63.3'ü göç öncesi yaşadığı gebelikte doğum öncesi kontrollerine gitmiş ve \%80.3'ü hastanede ve \%13.3'ü sağlık personeli yardımı almadan evde doğum yapmıştır. Göç sonrasında \%95.8'i gebe kalmış olup, yaşamış olduğu gebeliğinde ise $\% 97$ 'si sağlık kontrolüne gitmiş ve \%93'ü hastanede ve \%3.4'ü sağıık personeli yardımı almakasızın evde doğum yapmıştır. Kadınların, pap smear yaptırma durumları \%23.6, kadın doğum doktoruna gitme durumları ise $\% 90.3$ olup, \%78.9'u doğru perine temizliği yapmakta ve \%30.2'si vajinal akıntı şikâyeti yaşamaktadır.

Kadınların \%26.9'unun GSA toplam puanı 3 ve üzeri olarak saptanmış olup bu kadınların genel sağlık durumu riskli olarak kabul edilmektedir. Sağlık durumu riskli kabul edilen kadınların, gebelik $(3.80 \pm 0.23, \min : 1-m a k s: 11)$, abortus (0.40 \pm 0.07 , min:0-maks:3), küretaj olma $(0.26 \pm 0.05$, min:0maks:2) ve ölü doğum (0.21 \pm 0.07 , min:0-maks:3) sayı ortalamaları sağlıklı gruptan fazla olup, canlı doğum (2.93 \pm 0.19 , min:0-maks:8), yaşayan çocuk $(2.75 \pm 0.2$, min:0maks:8) sayısı ortalamaları sağlıklı gruptan azdır. İlk gebe

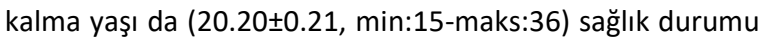

sağlıklı olan grupta riskli gruptan $(20.01 \pm 0.37$, min:14maks:31) daha yüksektir. Yapılan korelasyon analizine gore ise yalnızca ölü doğum sayısı ile GSA risk gruplandırması arasında düşük güçte pozitif yönde ilişki bulunmuştur ( $p<0.00, r:$.194).

GSA'ya göre sağlık durumu riskli çıkan kadınların yaş ortalamaları $(19.25 \pm 0.46)$ istatistiki olarak anlamlı bir şekilde sağlıklı gruba $(19.54 \pm 0.19)$ göre daha düşük saptanmıştır ( $\mathrm{U}: 8849.0, \mathrm{p}<0.01)$. Göç edilen yerde yaşanılan süre sağlık durumu riskli $(18.94 \pm 1.26)$ çıkan kadınlarda sağlıklı $(15.47 \pm 0.55)$ gruba göre daha yüksek bulunmuştur (U:9093.5, p<0.02) (Tablo 2).

Tablo 2. Göçmen Kadınların GSA'ya Göre Sağlık Risk Gruplarını Etkileyen Özelliklerinin Dağılımı

\begin{tabular}{|c|c|c|c|c|c|c|c|}
\hline $\begin{array}{l}\text { Kadınların } \\
\text { özellikleri }\end{array}$ & $\begin{array}{l}\text { GSA risk } \\
\text { grupları }\end{array}$ & $n$ & $\overline{\mathrm{X}} \pm \mathrm{SS}$ & \begin{tabular}{|l|} 
Medyan \\
- IR
\end{tabular} & $z$ & $\mathbf{U}$ & p \\
\hline \multirow[t]{2}{*}{ Yaş } & Sağııklı grup & 242 & $19.54 \pm 0.19$ & $30-12$ & \multirow[t]{2}{*}{-2.489} & \multirow[t]{2}{*}{8849.0} & \multirow[t]{2}{*}{$0.00^{*}$} \\
\hline & Risk grubu & 89 & $19.25 \pm 0.46$ & $30-14$ & & & \\
\hline \multirow{3}{*}{$\begin{array}{l}\text { Göç edilen } \\
\text { yerde } \\
\text { yaşanılan } \\
\text { süre (yıl) }\end{array}$} & Sağlıklı grup & 242 & $15.47 \pm 0.55$ & $15-10$ & \multirow[t]{2}{*}{-2.177} & \multirow[t]{2}{*}{9093.5} & \multirow[t]{2}{*}{$0.02^{*}$} \\
\hline & Risk grubu & 89 & $18.94 \pm 1.26$ & $18-49$ & & & \\
\hline & Total & 331 & & & & & \\
\hline
\end{tabular}

Kadınların genel sağlık durumunun evlenmeyi isteme durumlarına bağımlı olduğu istatistiksel olarak anlamlı bulunmuştur $\left(X^{2}=10.032 ; p<0.00\right)$. Evliliğini kendi isteğiyle yapmış olan kadınların \%75.6'sının sağlık durumu normal iken, istemeyerek evlenen kadınların ise \%51.7'sinin risklidir (Tablo 3).

Ayrıca kadınların genel sağlık durumları ile göç etmekten olumlu ve olumsuz etkilenme, sağlık durumlarının etkilenme, sağlık sorunu yaşama durumları, genel sağlık durumu algıları, göç etmekten memnuniyet, tekrar şans verilse göç etme isteği, aile planlaması yöntemi kullanma, göç öncesindeki gebeliğinde doğum öncesi kontrollerine gitme durumu ve doğumunu gerçekleştirmiş olduğu yer, göç sonrası gebeliğinde doğum öncesi kontrollerine gitme durumu ve vajinal akıntısı şikayeti yaşaması değişkenleri arasında bağımlılık istatistiksel olarak anlamlı bulunmuştur ( $p<0.05$ ) (Tablo 3).

Yapılan chaid analizine göre ise göç öncesi gebelik sağlık kontrollerini yaptıran kadınların \%90.8'inin genel sağlık durumu normal olup, bunlardan akıntı şikayeti yaşayanların $\% 29.2$ 'si ve yaşamayanların ise \%4.7'si riskli grupta bulunmaktadır. Ayrıca göç öncesi doğum öncesi kontrollerini yaptırmayan kadınların \%38.5'inin genel sağlık durumu riskli olup bunlardan göç etmekten memnun olmayanların \%76.5'inin ve memnun veya değişiklik olmadığını belirten kadınların \%35'inin riskli grupta olduğu saptanmıştır. Göç etmekten memnun veya herhangi bir değişiklik olmadığını belirten grubun adet düzeninde bozulma, sinirlilik, mutsuzluk, akıntı, akne, verem, astım, Yaşayanların ayak-baş ağrısı, kalp krizi, tansiyon ve romatizma gibi sağıık problemleri yaşayan kısmının \%71.7 oranında riske sahip olduğu, sağlık sorunu yaşamayan veya ruhsal bunalım, varis veya bel ağrısı yaşayanların ise \%22.6'sının riskli sağlık durumuna sahip olduğu belirlenmiştir (Şekil 1). 
Tablo 3. Göçmen Kadınların GSA'ya Göre Sağlık Risk Gruplarını Etkileyen Özelliklerinin Dağıımı

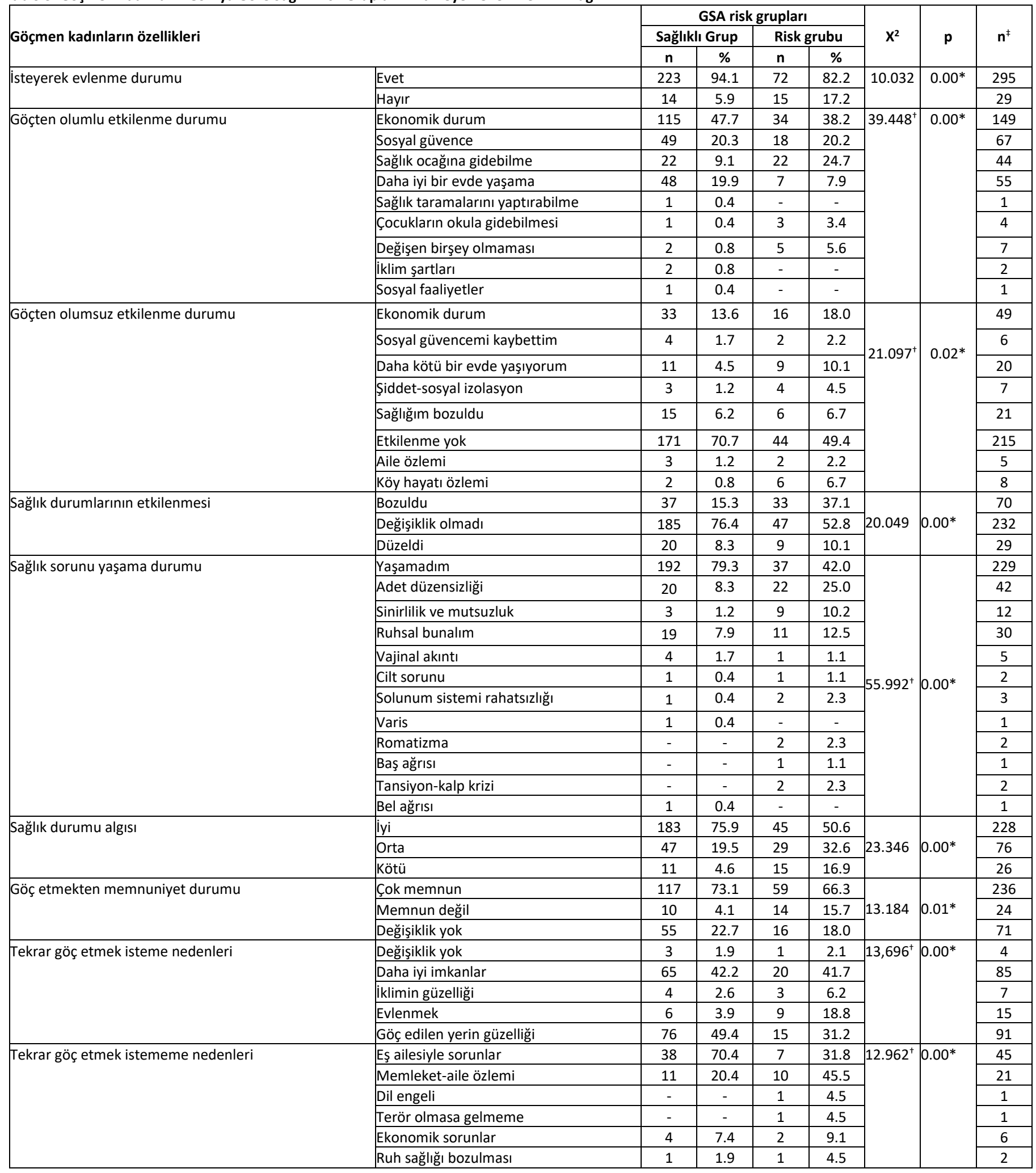


Tablo 3. Göçmen Kadınların GSA'ya Göre Sağlık Risk Gruplarını Etkileyen Özelliklerinin Dağııımı (devamı)

\begin{tabular}{|c|c|c|c|c|c|c|c|c|}
\hline \multirow{3}{*}{ Göçmen kadınların özellikleri } & & \multicolumn{4}{|c|}{ GSA risk grupları } & \multirow{3}{*}{$x^{2}$} & \multirow{3}{*}{$\mathbf{p}$} & \multirow{3}{*}{$\mathbf{N}^{\ddagger}$} \\
\hline & & \multicolumn{2}{|c|}{ Sağlıklı Grup } & \multicolumn{2}{|c|}{ Risk grubu } & & & \\
\hline & & $\mathbf{N}$ & $\%$ & $\mathbf{N}$ & $\%$ & & & \\
\hline \multirow[t]{2}{*}{ Aile planlaması kullanımı } & Kullanan & 153 & 63.5 & 45 & 51.1 & \multirow[t]{2}{*}{4.102} & \multirow[t]{2}{*}{$0.04^{*}$} & 198 \\
\hline & Kullanmayan & 88 & 36.5 & 43 & 48.9 & & & 131 \\
\hline \multirow[t]{2}{*}{ Göç öncesi gebelik sağlık kontrolü } & Giden & 119 & 71.7 & 12 & 29.3 & \multirow[t]{2}{*}{25.462} & \multirow[t]{2}{*}{$0.00^{*}$} & 131 \\
\hline & Gitmeyen & 47 & 28.3 & 29 & 70.7 & & & 76 \\
\hline \multirow[t]{4}{*}{ Göç öncesi doğum yapılan yer } & Hastane & 119 & 85.6 & 20 & 58.8 & \multirow[t]{4}{*}{$12.483^{+}$} & \multirow{4}{*}{$0.00 *$} & 139 \\
\hline & Sağlık ocağı, ASM & 2 & 1.4 & 1 & 2.9 & & & 3 \\
\hline & Sağlık personeli yardımıyla evde & 4 & 2.9 & 4 & 11.8 & & & 8 \\
\hline & Yardımsız evde & 14 & 10.1 & 9 & 26.5 & & & 23 \\
\hline \multirow[t]{2}{*}{ Göç sonrası gebelik sağlık kontrolü } & Giden & 221 & 98.7 & 74 & 92.5 & \multirow[t]{2}{*}{$5.791^{*}$} & \multirow[t]{2}{*}{$0.01 *$} & 295 \\
\hline & Gitmeyen & 3 & 1.3 & 6 & 7.5 & & & 9 \\
\hline \multirow[t]{2}{*}{ Vajinal akıntı sorunu } & Olan & 54 & 22.3 & 46 & 51.7 & \multirow[t]{2}{*}{26,624} & \multirow[t]{2}{*}{$0.00^{*}$} & 100 \\
\hline & Olmayan & 188 & 77.7 & 43 & 48.3 & & & 231 \\
\hline
\end{tabular}



Şekil 1. Göç Öncesinde Kadınların Sağlık Kontrolü Yaptırma Durumlarına Göre Genel Sağlık Durumunu Etkileyen Faktörlerin Chaid Analizi 


\section{TARTIŞMA}

Aydın iline göç eden, genel sağlık durumu riskli bulunan kadınların yaş ortalamasının sağlıklı gruba göre daha düşük olduğu saptanmıştır. Ayrıca göç edilen yerde yaşanılan süre artıkça kadınların sağıık durumu risk düzeyinin arttığı saptanmıştır. Çalışma sonucu ile benzer bir şekilde Kore'de yapılan bir çalışmada (2019) göçmen kadınların yaş ve göç edilen yerde kalma sürelerinin sağlık arayış davranışlarını etkileyerek sağıı taramalarını yaptırma oranlarının azaldığı saptanmıştı ${ }^{22}$. Genç yaştaki ve genellikle evlilik sonrası göç eden kadınların evliliğin getirdiği sorumluluklar, çocuk bakımı, aile üyeleri ile olan ilişkileri, göç edilen bölgeye uyumları, sağlık hizmetlerine erişimleri ve dil engeli gibi durumlar nedeniyle sağlık arayış davranışları etkilenerek zamanla sağlık durumlarının riskli duruma gelebileceği düşünülmektedir.

Çalışmaya katılan göçmen kadınların yaklaşık yarısı akraba evliliği yapmış ve bu kadınların \%38'i istemeden evlendirilmiştir. Hacettepe Üniversitesi Nüfus Etüdleri Enstitüsü Türkiye Nüfus ve Sağlık Araştırması (TNSA) (2018) verilerine göre akraba evliliği ülkemizde $\% 24$, Aydın ilinininde içerisinde bulunduğu Ege bölgesinde \%16, Aydın iline göç eden kadınlarının çoğunluğunun geldiği bölgelerden doğuda $\% 35$, güneydoğuda $\% 43$ oranında görülmektedir ${ }^{23}$. Dünya'da Türkiye'nin de içinde bulunduğu, Kuzey Afrika, Batı Asya ve Güney Hindistan, Pakistan gibi ülkelerde akraba evlilikleri kültürel ve sosyal olarak tercih edilmektedir ve tüm evliliklerin \%2050 'sini oluşturmaktadır ${ }^{24}$

Çalışmada yer alan kadınların \%38.4'ü geniş ailede yaşamakta, \%59.2'si eşinin ailesi ile evliliğinde sorunlar yaşamakta, \%27,6'sı memeleket-aile özlemi çekmekte, \%1.3'ü göç ettiği bölgenin dilini öğrenememiş, \%18.4'ü göç nedeniyle çalıştığı işi bırakmış, \%7.9'u ekonomik sıkıntı çekmekte, \%2.6'sı ruh sağlığı problemleri yaşamakta ve \%7.9'u sağlık durumunu kötü algılamaktadır. Bu bulgu kadınların kültürel nedenlerle yabancı bir ortamdaki hareket özgürlüklerinin giderek kısıtlanması, dil engeli yaşamaları, erkeklere oranla iş gücü piyasalarına katılımlarının daha zor olduğu, ve bu yüzden göç etmiş olan kadınların 'ev kadını' rolünü eskisine oranla daha fazla benimsemek zorunda kalmaları, gelir düzeyinin düşük olması, sağlık sigortalarının olmaması, sosyal destek ve statü kaybı, yalnızlık, kalabalık evlerde yaşamaları ve evlilikte eşler arasında problemler yaşanması gibi etkileri savunan literatür ile benzerdir ${ }^{2,8,11}$. Ayrıca ülkemizde yapılan bir çalışmada göç eden kadınların sağlıklı yaşam biçimi davranışlarının orta düzeyde olduğu ve sağlıklı yaşam biçimi davranışlarının medeni durum, öğrenim durumu, aile tipi, gelir durumunu algılama, sosyal güvence durumu ve sağlık sorunu değişkenlerinden etkilenmekte olduğu saptanmıştır ${ }^{18}$. Yapılan diğer bir çalışmada ise sosyoekonomik durumun özellikle çalışmayan göçmen kadınların sağlık taramalarına katılma oranını azalttığı belirtilmiştir ${ }^{22}$. Bu durum sağlık sigortası olmayan kadınların koruyucu sağlık hizmetlerinden yararlanamamalarına neden olabilmektedir ${ }^{13-15}$. Göç sonrası yaşanılan sorunların, göç edilen yerde daha uzun süre yaşayan kadınların göç memnuniyetini azaltarak genel sağlık durumunu olumsuz etkilendiği saptanmıştır.

Çalışmada istemeden evlenmiş olan göçmen kadınların GSA puanlarının olumsuz etkilendiği ve riskli gruba girdikleri bulunmuştur. Riskli grupta bulunan kadınların ilk gebe kalma yaşı daha düşük, gebelik, abortus, küretaj ve ölü doğum sayıları ise sağlıklı grupta bulunan kadınlardan daha yüksek olduğu saptanmıştır. Çalışma sonucunu destekler şekilde, tüm bu sorunlara neden olabilen, ilk gebelik yaşının düşük olmasının Aydın il merkezinde yapılan bir alan çalışmasında doğum öncesi bakım alma durumunu etkilediği belirtilmiştir ${ }^{25}$. TNSA (2018) verilerine göre ülkemizde doğum öncesi bakım alma oranı Ege ve Doğu bölgelerinde benzer şekilde \%95 bulunmuştur. Ayrıca ülkede modern aile planlaması yöntemi kullanımı \%77 iken bu oran Doğu bölgelerde \%43'e düşmektedir ${ }^{23}$. Çalışma verileri istemeden evlenen ve erken yaşta gebe kalan göçmen kadınların fiziksel ve emosyonel sağığının olumsuz etkilendiğini göstermektedir.

Çalışmada kadınların aile planlaması yöntemleri kullanma durumunun GSA puanlarını olumsuz etkilediği saptanmıştır. Bu verinin bir sonucu olarak sağlık durumu riskli kabul edilen kadınların, gebelik, abortus, küretaj olma ve ölü doğum oranlarının da sağlıklı gruptan fazla olduğu belirlenmiştir. Alan Dikmenin (2018) mülteci kadınlar ile yaptıkları bir çalışmada kadınların aile planlamasına yönelik tutumlarının orta düzeyde olduğu ve bu tutumlarının eşlerinden etkilendiği tespit edilmiştir ${ }^{26}$. Çalışmada istemeden evlenmenin kadınların GSA puanlarının olumsuz etkilenmesinin ve kadınların eşlerinin ailesiyle yaşadıkları sorunlar olduğunu bildirmelerinin, aile planlaması yöntemlerini kullanmaları ile genel sağlık arayış davranışlarının etkilenmesinin eş tutumlarından kaynaklanabileceğini düşündürmektir. Ayrıca gebelik süresince depresyon bulguları gösteren göçmen kadınların birçoğunun kontraseptif yöntem kullanmamaları nedeniyle istenmeyen gebeliğe ve yetersiz eş desteğine sahip olduğu yapılan başka bir çalışmada belirtilmiştir ${ }^{27}$. Literatür ile benzer şekilde tüm bu nedenlerle çalışmada yer alan kadınların ruh sağlığının etkilediği düşünülmektedir.

Çalışmada kadınların dörtte biri, bir şansları daha olsa Aydın iline tekrar göç etmek istemediklerini belirtmiştir. Bu kadınlar eşlerinin ailesi ile sorun yaşadıklarını, memleket ile aile özlemi çektiklerini, ekonomik sorunlar ve dil engeli yaşadıklarını, terör olmasa idi buraya gelmeyeceklerini ve ruh sağlıklarının bozulduğunu ifade etmiştir. Yaşanılan bu sorunlardan kaynaklanan stresin beden fizyolojisini etkileyerek kadınların menstrual sikluslarında düzensizliğe ve ruhsal problemlere neden olarak sağlık durumunu bozduğu ve GSA puanlarını olumsuz etkilediği düşünülmektedir. Ayrıca göçmen kadınların stresle baş etmede daha yetersiz olduğu belirtilmektedir ${ }^{2}$. Rios Casas ve arkadaşları çalışmalarında (2020) göçmenlerin göç ile birlikte kopan sosyal çevreleri ile olan bağlarının ve sağlık ile sosyal hizmetlere olan sınırlı erişim olanaklarının yaşadıkları temel stresörlerden olduğunu belirtmişlerdir ${ }^{28}$.

Göç etmekten memnun olan göçmen kadınlar da dahi adet düzeninde bozulma, sinirlilik ve mutsuzluk gibi sağlık problemleri olduğu saptanmıştır. Göç etmekten memnun olan bu kadınların büyük bir kısmının her hangi bir sağlık sorunu bildirmemelerine rağmen sağlık durumlarının riskli olduğu saptanmıştır. Yapılan bir çalışmada göçmen kadınların birden fazla hastalığa sahip olma oranının $\% 40$ olduğu ve sıklıkla ülser rahatsızlığı yaşadıkları belirtilmiştir ${ }^{22}$. Literatürde göçün ruh sağlığını olumsuz yönde etkilediğini belirten birçok çalışma da vardır8,9. Yapılan bir sistematik incelemede gelir düzeyi yüksek ülkelere göçen kadınlar arasında \%52'ye varan postpartum depresyon saptanmıştır ${ }^{29}$. Bu durum göçmen kadınların yaşadıkları stres ile başetmede zorlandıklarını ve emosyonel durumlarının etkilendiğini göstermektedir.

Çalışma da göçmen kadınların \%4.5'i dil engeli nedeniyle GSA puanlarına göre riskli grupta saptanmış olup, bir şansı daha olsa tekrar Aydın'a göç etmek istemediğini bildirmiştir. Bu kadınların dil 
engeli nedeniyle sağlık hizmetlerine ulaşmada sorun yaşadıkları düşünülmektedir. Yapılan araştırmalarda göçmenlerin sağlık bakımı hizmetlerinden yararlanmalarını ve sağlık bakımı almalarını etkileyen önemli faktörlerden birinin dil problemi olduğu belirtilmektedir ${ }^{8,11,12}$. Önal ve arkadaşlarının (2016) yaptıkları çalışmada da göçmenlerin sağık hizmetine erişimde yaşadığı problemler arasında beş temel faktör olan; hekimlerin olumsuz tutumu, sağlık personelinin olumsuz tutumu, iletişim sorunu, sağlık hizmetlerinin işleyişinde yaşanabilecek olumsuzluklar ve maddi yetersizlikler tespit edilmiştir ${ }^{30}$. Bir sistematik gözden geçirme çalışmasında sağlık personelinden olumsuz davranışlar deneyimleyen göçmenlerin antenatal bakım hizmetlerinden yararlanmaktan kaçındıkları belirtilmiştir ${ }^{31}$. Ortiz ve arkadaşlarının çalışmasında da (2019) göçmen kadınların yerli kadınlara oranla 13. gebelik haftasından sonra ve beşten az antenatal bakım aldıkları saptanmıştır ${ }^{32}$. Taşçı Duran'ın çalışmasında da (2016) göçmen kadınların eğitim düzeyi, kararları alma durumları, birlikte yaşadıkları kişiler, gebelik sayısı, gelir durumu, sağlıkla ilgili konularda insanlara danışma, etnik köken, mezhep, iletişim değişkenlerinin doğum öncesi bakım alma konusunda niyet ve tutumları etkilediği belirlenmiştir ${ }^{33}$. Yaptığımız çalışmada literatürün aksine göçmen kadınların antenatal bakım hizmetlerinden yararlanmalarının arttığı, evde doğum yerine hastaneye yöneldikleri, terör korkusu olmadan ve ılımlı iklim koşulları sayesinde çocuklarını okula gönderebildikleri ve sağlık ocağına gidebildikleri saptanmıştır ${ }^{2,5,8}$.

Ayrıca çalışma da kadınların doğum yaptıkları yerin GSA puanlarını olumsuz etkilediği saptanmıştır. Ölü doğum yapmaları ile kadınların genel sağlık durumunun riskli olması ilişkili bulunmuştur. Çalışma ile benzer şekilde gelişmiş ülkelerde yapılan birçok çalışmada, göçmen annelerin gebelik sonuçlarının yerli annelere göre daha kötü olduğu belirtilmektedir ${ }^{14,16,27,31}$. Bollini ve arkadaşlarının (2009), 1966-2004 yıllarında 12 ülkeden 65 çalışmayı incelemişler ve göçmen kadınların \%43'ünün Düşük Doğum Ağırlıklı Bebek (DDAB) doğurma, $\% 24$ 'ünün preterm doğum, $\% 50$ 'sinin perinatal mortalite, \%61'inin konjenital anomali risklerine sahip olduğunu ifade etmişlerdir ${ }^{16}$. Ancak Ortiz ve arkadaşlarının (2019) Şili'de yerli ve göçmen kadınlar arasında yaptıkları çalışmaların da ise yerli kadınların yaş ortalamaları düşük olmasına rağmen obstetrik mortalite, preeklampsi, gestasyonel diyabet, obezite prematurite ve sezaryen doğum oranlarının göçmen kadınlardan daha yüksek olduğunu, düşük doğum ağırlığı arasında bir fark olmadığını saptanmışlardır ${ }^{32}$. Benzer şekilde TNSA 2018 verilerinde de ülkemize göç eden Suriyeli göçmen kadınların yerli halk ile benzer oranlarda \%96 doğum öncesi bakım alıp, \%99 sağılı kurumunda doğum yaptıkları ve sezaryen doğum yapma oranlarının \%27 iken yerli halkın \%52 olduğu saptanmıştır ${ }^{23}$.

Tüm bu bulgulara ek olarak, çalışmada literatürle benzer şekilde göçmen kadınların \%20'sinin sosyal güvencesinin olmadığı, pap smear testi yaptırmadığı, hatalı perine hijyeni uyguladığı ve vajinal akıntı problemi olduğu bulunmuştur $2,8,11,18$. Çalışma da kadınların vajinal akıntı yaşamalarının GSA puanlarını olumsuz etkilediği saptanmıştır. Kadınların göç sonrası ekonomik durumlarının etkilenmesi sosyal güvencelerinin olmamasına, yaşadıkları ortam koşulları ve kültürel nedenlerin hijyenlerine özen gösterememelerine, sağlık hizmetlerine erişim ya da personelin gerekli eğitimleri yapmamaları nedeniyle pap smear testi yaptıramamalarına neden olmuş olabileceği düşünülmektedir. Ülkemizde yaşayan göçmen kadınlarda en çok karşılaşılan sağlık problemleri arasında bulaşıcı hastalıklar, vajinal enfeksiyonlar, aile planlaması ve doğum öncesi bakım hizmetlerinden yararlanamama, hastanede yapılan doğum sayısının az, evde yapılan doğumların sayısının çokluğu, düzensiz adet kanamaları, kendiliğinden meydana gelen düşükler, çok sayıda ve kısa aralıklarla meydana gelen gebelikler yer almaktadır ${ }^{34,35}$.

\section{SONUÇ ve ÖNERILER}

Araştırma sonucunda Aydın Illi'ne iç göç ile gelen kadınların çoğunluğunun genel sağılık durumunun iyi olduğu saptanmıştır. Genel sağlık durumu riskli çıkan kadınların obstetrik bulgularının daha kötü durumda olduğu ve bu bulguların göç edilen yerdeki sürenin artması ile doğru orantılı olarak kötüleştiği görülmüştür. Yaşanılan sağıı sorunları arasında sıklıkla menstrual siklus düzensizliği ve ruhsal bunalım gibi problemler yer almaktadır. Ancak sağlık sorunu yaşamayan ve göç etmekten memnun olan grupta dahi Genel Sağlık Anketi riskli olan kadınlar saptandığı için tüm göçmen kadınlara; aile planlaması yöntemleri, genital hijyen, gebelik ve genel sağılı taramaları gibi konularında eğitimler verilmesi, psikolojik destek almalarının sağlanması, sağlık kontrollerinin öncelikli grup olmaları sağlanarak daha sık yapılması ve ekonomik durumlarına devlet tarafından iş imkanları yaratılarak destek olunması gerekmektedir.

Araştırmada yaş ortalaması düşük, kendi isteği ile evlenmeyen ve göç etme süresi uzun olan kadınların daha fazla sağlık riski ile karşı karşıya kalındığı görülmektedir. Bu doğrultuda göç eden kadınların karşılaştıkları ön yargılar giderilip, diğer bireylerle iletişim kurmaları sağlanarak, destekleyici bir çevre yaratılmalı, sağlık hizmetleri yapılan ev ziyaretleriyle daha kolay ulaşılır ve pratik çözüm önerileriyle daha az maliyetli hale getirilmelidir.

Etik Kurul Onayı: Aydın Adnan Menderes Üniversite'sinin Girişimsel Olmayan Klinik Araştırmalar Etik Kurulu'ndan alınmıştır (Karar No: 2016/813, Karar Tarihi: 01.06.2016).

Çıkar Çatışması: Yoktur.

Finansal Destek: Bildirilmemiştir.

Katılımcı Onamı: Kadınlardan bilgilendirilmiş onam alınmıştır. Yazar katkıları:

Araştırma dizaynı: HA, HY, SÖ, MT

Veri Toplama: HY, SÖ

Veri Analizi: MT, HY

Makale Yazımı: HY, HA

Teşekkür: Çalışmaya katılan tüm göçmen kadınlara teşekkür ederiz. Ethics Committee Approval: Approval was obtained from Noninterventional Clinical Research Ethics Committee of Aydın Adnan Menderes University (Decision number: 2016/813).

Confict of Interest: Not reported.

Funding: None.

Exhibitor Consent: Informed consent was obtained from women. Author contributions:

Study design: HA, HY, SO, MT

Data collection: $\mathrm{HY}, \mathrm{SO}$

Data analysis: MT, HY

Drafting manuscript: $\mathrm{HY}, \mathrm{HA}$

Acknowledgement: We would like to thank all immigrant women who participated to the study. 


\section{KAYNAKLAR}

1. Çelik F. Türkiye'de iç göçler: 1980-2000. Sosyal Bilimler Enstitüsü Dergisi. 2007;22(1):87-109.

2. Topçu S, Başer A. Göç ve sağlık. CÜ Hemşirelik Yüksekokulu Dergisi. 2006;10(3):37-41.

3. Adanu RMK, Johnson TRB. Migration and women's health. Int J Gynecol Obstet. 2009;106(2):179- 81.

4. Unites Nations General Assembly-UN. Seventy-third session, international migration and development, report of the secretary- general. [Internet]. 2018 [Erişim Tarihi 21 Şubat 2021]. Erişim adresi: https://www.un.org/en/development/desa/population/mi gration/generalassembly/reports/index.asp

5. TUIK- Turkish Statistical Institute. Adrese dayalı nüfus kayıt sistemi sonuçları: Göç İstatistikleri [Address based population registration system results]. [Internet]. 2019 [Erişim Tarihi 05 Nisan 2020]. Erişim adresi: https://tuikweb.tuik.gov.tr/PreTablo.do?alt_id=1067

6. Sirin A, Kavlak O, Sen E, Yagcan H. The effects of internal migration on women's health in Turkey. Journal of Human Sciences. 2011;8(1):1019-27.

7. Aksu H, Sevil Ü. Göç ve kadın sağlığı. Maltepe Üniversitesi Hemşirelik Bilim ve Sanatı Dergisi. 2010;2(3),133-38.

8. Tuzcu A, Ilgaz A. Göçün kadın ruh sağlığı üzerine etkileri. Psikiyatride Güncel Yaklaşımlar. 2015;7(1):56-67.

9. Sır A, Bayrami $Y$, Özkan M. Zoraki iç göçün ruh sağlığına etkileri üzerine bir ön çalışma. Klinik Psikiyatri Dergisi. 1998;1(2):83-8.

10. Miller E, Decker MR, Silverman JG, Raj A. Migration, sexual axploitation and women's health: a case report from a community health center. Violence Against Women. 2007;13(5):486-97.

11. Çalım SI, Kavlak O, Sevil Ü. Evrensel bir sorun: göç eden kadınların sağlığı ve sağlık hizmetlerinde yaşanan dil engeli. Sağlık ve Toplum. 2012;22(2):11-9.

12. Fassaert $T$, Hesselink AE, Verhoeff AP. Acculturation and use of health care services by Turkish and Moroccan migrants: a cross-sectional population -based study. BMC Public Health. 2009;10(9):332.

13. Fuantes-Afflick $E$, Hessol NA. Immigration status and use of health sevices among Latina women in the San Francisco bay area. J Womens Health (Larchmt). 2009;18(8):1275-80.

14. Paz-Zulueta M, Llorca J, Santibáñez $M$. Disparities in access to prenatal care services for African immigrant women in Spain. J Immigr Minor Health. 2015;17(5):1355-63.

15. Raymond-Flesch $M$, Siemons $R$, Pourat $N$, Jacobs $K$, Brindis $C D$. There is no help out there and if there is, it's really hard to find: a qualitative study of the health concerns and health care access of Latino "DREAMers". J Adolesc Health. 2014;55:323-28.

16. Bollini $\mathrm{P}$, Pampallona $\mathrm{S}$, Wanner $\mathrm{P}$, Kupelnick B. Pregnancy outcome of migrant women and integration policy: a systematic review of the international literature. Soc Sci Med. 2009;68(3):452-61.

17. Urguia $M L$, Glazier $R H$, Mortensen $L$, Nybo-Andersen $A M$, Small R, Davey $M A$, et al. Severe maternal morbidity associated with maternal birthplace in three highimmigration settings. Eur J Public Health. 2015;25(4):620-25.
18. Demir G, Arıöz A. Göç eden kadınların sağlıklı yaşam biçimi davranışları ve etkileyen faktörler. DÜ Sağlık Bil Enst Derg. 2014;4(2):1-8.

19. Esteban $M M$, Puerto $M I$, Fernandez Cordero $X$, Jimenez Garcia R, Gil de Miguel A, Hernandez Barrera V. Determinants of poor mental health in people aged 16 to 64 residing in a large city. An. Sist. Sanit. Navar. 2012;35(2):22940.

20. Goldberg DP, Williams P. A user's guide to general health questionnaire. UK: Windsor, Berks, NFER/Nelson; 1998.

21. Kılıç C. Genel sağlık anketi: güvenilirlik ve geçerlilik çalışması. Türk Psikiyatri Dergisi. 1996;7:3-9.

22. Jeong J, Lee $\mathrm{Y}$, Kwon SH, Myong JP. Factors associated with general health screening participation among married immigrant women in Korea. Int J Environ Res Public Health. 2019;16(20):3971.

23. Hacettepe Üniversitesi Nüfus Etütleri Enstitüsü. 2018 Türkiye nüfus ve sağlik araştirmasi-TNSA [Turkey Demographic and Health Survey-TDHS]. Ankara: Hacettepe University Institute of Population Studies in collaboration with T.R. Ministry of Health and T.R. Prime Ministry Undersecretary of State Planning Organization TÜBITAK, 2019.

24. Hamamy H. Consanguineous marriages: Preconception consultation in primary health care settings. J Community Genet. 2012;3(3):185-92.

25. Beşer E, Ergin F, Sönmez A. Aydın il merkezinde doğum öncesi bakım hizmetleri. TSK Koruyucu Hekimlik Bülteni. 2007;6(2):137-41.

26. Alan Dikmen H, Cankaya S, Dereli SY. The attitudes of refugee women in Turkey towards family planning. Public Health Nurs. 2018;36(1):45-52.

27. Coller KM, Chao SM, Lu MC, Strobino D. Unintended births among adult immigrant and U.S.-born Mexican women in the Los Angeles mommy and baby (LAMB) survey. Women's Health Issues. 2014;24(4):e365-72.

28. Rios Casas F, Ryan D, Perez G, Maurer S, Tran AN, Rao D, et al. "Se vale llorar y se vale reír": Latina immigrants' coping strategies for maintaining mental health in the face of immigration-related stressors. J Racial Ethn Health Disparities. 2020;7(5):937-48.

29. Nilaweera I, Doran F, Fisher J. Prevalence, nature and determinants of postpartum mental health problems among women who have migrated from SouthAsianto high-income countries: A systematic review of the evidence. J Affect Disord. 2014;166:213-26.

30. Önal A, Keklik B. Mülteci ve sığınmacıların sağlık hizmetlerine erişimde yaşadığı sorunlar: Isparta ilinde bir uygulama. Süleyman Demirel Üniversitesi Vizyoner Dergisi. 2016;7(15):132-48.

31. Higginbottom GMA, Evans C, Morgan M, Bharj KK, Eldridge $J$, Hussain B. Experience of and access to maternity care in the UK by immigrant women: a narrative synthesis systematic review. BMJ Open. 2019;9(12):e029478.

32. Ortiz J, Diaz M, Araya BM, Quiroz J, Carroza B, Pavez J, et al. Comparison of bio-sociodemographic, obstetric and perinatal characteristics among immigrant and native women in the Metropolitan Region in Chile. Midwifery. 2019;75:72-9. 
33. Taşçı-Duran E. Göç eden gebe kadınların planlı davranış kuramına göre doğum öncesi bakım almaya yönelik niyet ve tutumlarını etkileyen etmenler. Hacettepe Üniversitesi Hemşirelik Fakültesi Dergisi. 2016;3(1):1-15.

34. Erenel H, Aydogan Mathyk B, Sal V, Ayhan I, Karatas S, Bebek Koc A. Clinical characteristics and pregnancy outcomes of Syrian refugees: a case-control study in a tertiary care hospital in Istanbul, Turkey. Arch Gynecol Obstet. 2017;295(1):45-50.

35. Kurtuldu K, Şahin E. Göçün kadın yaşamı ve sağlığı üzerine etkileri. Ordu Üniversitesi Hemşirelik Çalışmaları Dergisi. 2018;1(1):37-46. 